\title{
Related to Indonesian Learning with the Environment
}

Silina Rosa Oktaviani/19016052

\section{Silvinarosa0810200@gmail.com}

The environment is an influential component in the implementation of teaching and learning activities. The environment can also support the course of teaching and learning activities in schools. Environmental education is an effort to preserve, maintain the environment, and ecosystems of living things in order to provide balance in the sustainability of life. Environmental education is very important in human life because environmental education can prevent damage to the environment.

According to Sukma et al (2020) environmental education is a field of education that arises when there is environmental distortion due to human efforts to master nature. Environmental education is an effort to preserve, maintain the environment, and ecosystems of living things in order to provide balance in the sustainability of life. According to Ramadhan et al (2019) environmental damage will result in an ecological crisis that causes a series of natural problems of resources, climate, pollution, food, and economy due to the environment that determines life, public health, as well as spiritual and moral development. Sukma et al (2020) states that environmental education is a field of education that arises when there is an environmental distortion due to human efforts to master nature. Most humans think only of themselves regardless of the impact it produces if they don't take care of the environment. For example, people often throw garbage into rivers that cause flooding. Therefore, self-awareness is needed to maintain this environment. This can be done by connecting the environment with the learning process Indonesian.

According to Kridalaksana (Suardi et al, 2019) the nature of language is an arbitrary system of sound symbols used by members of social groups to cooperate, communicate, and identify themselves. Social development and the formation of children's social identity are related to the acquisition of language. The relationship between language acquisition and language learning is usually different. Language acquisition is obtained in the environment of daily life whereas language learning is obtained formally by adhering to concepts. The environment around children, especially the family environment, plays an important role in language acquisition because after language acquisition, children experience language learning. Therefore, the family environment is a major role in instilling knowledge, values and attitudes about the environment to children. Because according to Ramadhan et al (2019) environmental education aims to invite children to participate in maintaining the environment and so that children can participate in maintaining the environment. One of the learning that has an important role in the education of the human environment is Indonesian learning.

Sukma (2017) states that the ability to be literate has a significant influence on students' success in learning and daily life. Through good literacy skills, it will assist students in understanding oral texts, writing, and visual texts. Sukma (2019) states that teachers should provide motivation to students. Through this motivation a teacher can create a variety of learning experiences for students. Indriyani et al (2019) stated that student literacy needs to be improved, 
especially literacy. Then, it is also necessary to know how the implementation of literacy that has been carried out in schools. Sukma (2020) stated that the planting of important characters was instilled since students were still sitting in elementary school. Character planting can be done in the learning process in school.

The amount of diversity of characters and habits of students in school come from different family backgrounds is a big influence that gives rise to bad things from bad child characters. Regarding the relationship of creativity of students with their environment, Munandar (Piliang et al, 2014) states that creativity is the result of individual interaction with their environment, it seems clear that individual creativity is largely determined by the drive or motivation from within and the environment. The things that have been mentioned before will later be related and affect student learning outcomes. The statement is in line with the opinion of Zulhafizh et al (2013) stating that students' learning attitudes and motivations contribute to their learning outcomes, namely Indonesian.

The environment in learning Indonesian beneficial for students or children in conveying ideas and feelings using good language. Therefore, it is necessary to use good and correct Indonesian in order to be able to increase students or children's knowledge about the environment that can be used also to develop thinking and communicative skills in using environmental materials. Learning titled environment aims to make learners participate in protecting the environment. This can be achieved by the implementation of lesson study in Indonesian learning.

In order for students to participate in maintaining the environment, it is important to develop knowledge about the environment, environmental concerns and behavioral changes to the environment. In environmental education, teachers also play an important role in the teaching of environmental education because teachers produce knowledge, beliefs, and skills of environmental conservation and protection of nature. This is in line with the statements of Sukma (2012) and Ramadhan et al (2019) which are teachers serving as facilitators and learning managers in the learning process.

Teachers Indonesian have an important role because language is not only used in communicating but Indonesian has a connection with other sciences. Kiyanti stated that literary works have a connection with educational and learning issues. Therefore, it is very wrong if the world of education always considers the field of exata more important than the social sciences or human sciences (Sukma et al, 2016). Therefore, by incorporating environmental education into language classes can increase students' interest and motivation in environmental education through a meaningful language learning process.

Based on the study of the authors $57.8 \%$ agree, $42.2 \%$ strongly agree, $0 \%$ disagree, and $0 \%$ disagree that environmental material needs to be included in learning Indonesian. $60 \%$ of respondents agreed, $37.8 \%$ strongly agreed, $3.2 \%$ disagreed, and $0 \%$ disagreed that environmental material was an interesting topic to learn, especially in Indonesian learning. 60\% agree, $40 \%$ strongly agree, $0 \%$ disagree, and $0 \%$ disagree that environmental conservation efforts can be included in reading texts Indonesian. Forty percent of respondents agreed, 57.8 percent strongly agreed, 3.2 percent disagreed, and 0 percent disagreed that teachers have an important contribution in introducing environmental knowledge through classroom learning. Respondents $51.1 \%$ agreed, 
$46.7 \%$ strongly agreed, $3.2 \%$ disagreed, and $0 \%$ disagreed that learning Indonesian based on the environment can increase the creativity of learners. A total of $31.1 \%$ of respondents agreed, $68.9 \%$ strongly agreed, $0 \%$ disagree, and $0 \%$ disagree that environmental matter is material that is very closely related to everyday life. $60 \%$ agree, $40 \%$ strongly agree, $0 \%$ disagree, and $0 \%$ disagree that learning about environmental material can directly or indirectly develop a learner's mindset. A total of $44.4 \%$ of respondents agreed, $55.6 \%$ of respondents strongly agreed, $0 \%$ disagreed, and $0 \%$ disagreed that learning Indonesian improve students' communication skills in the community environment. A total of $44.4 \%$ agreed, $51.1 \%$ strongly agreed, $6.4 \%$ disagreed, and $0 \%$ disagreed that the environment could be used as a medium in learning Indonesian. Forty percent of respondents agreed, 57.8 percent strongly agreed, 3.2 percent disagreed, and 0 percent disagreed that environmental material in learning Indonesian fostering the attitude of students who care about the environment.

Based on the results of the study it can be concluded that environmental education plays an important role in life. Therefore, to maintain and preserve the environment requires understanding and knowledge about the environment. Learning Indonesian has an important role in environmental education because teachers produce environmental knowledge and are delivered to students. In addition, parents also play an important role to help students or children to care more about the environment. Parents who give encouragement and encouragement to students to increase their concern for the environment. 


\section{DAFTAR PUSTAKA}

Piliang, Wilda S. H., Atmazaki, dan Syahrul Ramadhan. (2014). Kontribusi Kemampuan Apresiasi Sastra dan Berpikir Kreatif terhadap Keterampilan Bermain Drama pada Siswa Kelas XII IPS SMA Negeri 2 Rengat Kabupaten Indragiri Hulu. Jurnal Bahasa, Sastra dan Pembelajaran, 2(2), 75-87.

Ramadhan, S., Elfia Sukma, dan Vivi Indriyani. (2019). Environmental education and disasternference Series: Earth and Environmental Science, 314.

Ramadhan, S., Elfia Sukma, dan Vivi Indriyani. (2019). Environmental Educatiion Through Language Learning. IOP Conference Series: Earth and Environmental Science, 314, p. 19.

Ramadhan, S., Elfia Sukma, dan Vivi Indriyani. (2019). Persepsi Guru terhadap Penggunaan Bahan Ajar Bahasa Indonesia dengan Perangkat Seluler dan Aplikasi Edmodo. Seminar Internasional Riksa Bahasa.

Suardi, I.P., Syahrul R, dan Yasnur Asri. (2019). "Pemerolehan Bahasa Pertama pada Anak Usia Dini”. Jurnal Obsesi: Jurnal Pendidikan Anak Usia Dini. 3(1): 265-273.

Sukma, Elfia. (2012). "Pembelajaran Sastra yang Integratif Berbasis Kompetensi". International Conference on Languages and Arts. Universitas Negeri Padang, FBS, 432-436.

Sukma, Elfia dan Ahmad J.S. (2016). "Kompetisi Kognitif Pembelajaran Apresiasi Sastra di Sekolah Dasar. Jurnal Penelitian Bahasa dan Sastra Indonesia. 2(1):1-11.

Sukma, Elfia, S. Ramadhan, V. Indriyani. (2020). Integration of environmental education in elementary schools. Journal of Physics: Conference Series 1481(1), p. 012136) IOP Publishing.

Sukma E. et.al. (2019). Problems in Oral Language Teaching in Primary School. Advances in Social Science. Education and Humanities Research, Volume 301: ISSN 2352-5398.

Sukma E, Ritawati M, dan Rizky A. (2017). Literacy Media Development in Improving Reading and Writing Skill of Early Class Students in Elementary School Padang Utara Padang. Advances in Social Science, Education and Humanities Research, Vol 118: ISSN 23525398 .

Zulhafizh, Atmazaki, dan Syahrul Ramadhan. (2013). Kontribusi Sikap dan Motivasi Belajar Siswa terhadap Hasil Belajar Bahasa Indonesia. Jurnal Bahasa, Sastra dan Pembelajaran, 1(2): 13-28. 